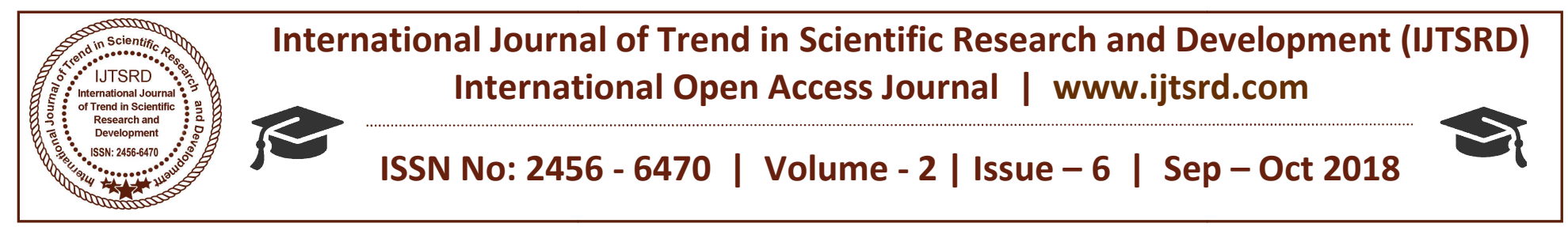

\title{
The Creation of Abuja, Nigeria Slums: A case of Abuja, Nigeria's failed Master Plan Implementation
}

\author{
Obiadi, Bons N., Nzewi N. U., Onochie, Aloysius Osita \\ Department of Architecture, Faculty of Environmental Sciences, Nnamdi \\ Azikiwe University, Awka, Anambra State, Nigeria
}

\begin{abstract}
Abuja is the viable outcome of an ambitious national dream that is transforming a virgin savannah terrain into the show piece capital of the most populous black nation-Nigeria. Abuja officially became the capital of Nigeria on 12, December 1991. In establishing Abuja, a Master Plan was developed. The Master Plan was prepared such that land use, infrastructure, housing, transportation, recreation, economic and social services were to be coordinated and inter-related however, successive governments in Abuja neglected the principles and that in urban slums. It is the aims of this paper, to evolve modalities for spatial housing design capable of remedying the existing urban spatial distortions, in a sustainable manner within the Central City areas. The authors adopted content base analysis, targeted data from both primary and secondary sources. The Abuja Master Plan was elaborated to put in place, a sustainable urban spatial environment for all groups or classes of activities to be carried out in the Capital Territory. The Master Plan actually provided for low-income settlements areas, to be built by the government and to be occupied by the public servants; the private sector servants did not appear to be properly provided for and that led to Abuja slums. The goals and objectives of the Master Plan, development laws, the use of professionally trained staff in the execution and implementation of the Master Plan and integration of the informal settlements into the formal settlement areas of the Central City are recommended.
\end{abstract}

Keyword: architecture, master plan, urban development, implementation, urban actors housing

\section{INTRODUCTION}

The roots of urbanization go deep into human history. The conventional theory was well stated by Lewis
Mumford (1961). He identified the first germ of the city in the ceremonial meeting place that serves as a goal for pilgrimage, a site to which early man with his family or clan group is drawn back from his wanderings at seasonable intervals because it concentrates, in addition to any natural advantage it may have, certain spiritual or super national powers. From periodic meetings a few steps lead to settlement and agriculture, to villages and finally, to a differentiation of villages in terms of concentration of technical and religious power, the seats of power becoming towns' vis-à-vis the villages. In a counter thesis, Jane Jacobs (1969) advanced the claims of the city above those of the village. She argues that historically it was the development of cities that made possible and necessary the development of satellite agricultural villages; that agriculture was indeed "farmed out" from the city to the countryside.

Okonkwo (2006), in an article, "the Building of a New Capital and its Local Communities: Abuja Federal Capital City on Focus," made a detailed and extensive studies of the reasons for the development of New Capitals and the study of Abuja FCT. It is out of his explanations that the present authors extracted greater part of what is presented in this section, as it were an account of Abuja's geographic information and development objectives. Whatever its origins and individual peculiarities, an urban center is distinguished most fundamentally by its functions. It is essentially a central place, a center for the mobilization and organization of services for an area. The "basic" urban functions, which generally have to do with administration, commerce, industry, transportation, are facilitated by aggregation. This is in marked contrast to primary production-agriculture, forestry, fishing, mining, extraction and the like - 
which, spread over favorable sites tied to available sources, is necessarily dispersed (Ukwu, 1980).

Walter Christaller (1966), the pioneer urban theorist whose formulation of the problem remained the most elegant, in modern times, in its logic and simplicity, has likened the process of town formation to "the crystallization" of mass about a nucleus". The number, scale and variety of facilities and services concentrated about a given nucleus determine its status as a town and reflect the size and character of its hinterland.

For a given region, the historical process of urban development does not depend on a steady unidirectional pattern of concentration and coalescence of urban facilities and services about a number of given centers. Rather it hinges on a series of critical events in the socio-economic organization of the communities, events which create new nuclei or enlarge, change the character, diminish or destroy preexisting ones, hence, the development of towns or systems of towns tends to be episodic and it is often possible to identify the key events and the phases of urban development associated with them.

Each key event imposes a new set of area relationships and a new functional ordering of centers thereby setting the scene for a new phase in urban development. This phenomenon has underscored urban development processes in Nigeria, more than ever since the colonial period (Okonkwo, 1993). The first new towns were created in Nigeria during the colonial period; and they were not created to absorb population over-spill from oversized urban centers, but rather to satisfy the economic and administrative interests of the colonial masters. It was in this way that Enugu and Jos were founded essentially for the exploitation of coal and tin resources, respectively, and Kaduna for administrative convenience (Mabogunje, 1968). Consequently, in its post-colonial period, many urban centers have come into existence while others have received more growth impetus under the political instrument of state and local government area creation, as well as the reallocation and redistribution of resources under the process of socio-economic restructuring in the country.

With the relocation of Nigerian capital from Lagos to Abuja, the new capital today stands out as the most important event that is changing hitherto center-tocenter relationship in Nigeria. One way of expressing national goals has been through the establishment of new towns. The two major reasons for these are: one, as capitals for countries which had little urban development or where the colonial capital was poorly placed for national needs, and two, as centers for industry (Pitte, 1977; Bell, 1981). Historically, Abuja is the viable outcome of an ambitious national dream that is transforming a virgin savannah terrain into the show piece capital of the most populous black nationNigeria. Most great cities around the world enjoy a substantial amount of patronage and reputation by virtue of two major factors, among numerous others, namely: "the visual amenity", defined as the general attractiveness of the environment, and "the cultural content" of the city, which is a property of the city capable of projecting significant aspects of the lifestyle of its inhabitants to the international community (Uloko, 2005). As already pointed out earlier, one way of expressing national goals has been through the establishment of new towns; as capitals for countries which had little urban development or where the colonial capital was poorly placed for national needs, and also as centers for industry. Abuja City is a response to these two last reasons.

\section{Lagos as Old Capital of Nigeria:}

City building in Nigeria dates back far into the country's pre-colonial era. A good number of wellestablished small towns had formed a strong contrast with the prevailing village types and scattered settlements. But the British bombardment and occupation of Lagos in 1851, in order to put an effective end to the slave trade in that coastal area of the country, marked the beginning of the end of precolonial urbanization in Nigeria (Mabogunje, 1968). During the colonial period, a number of factors combined to revolutionize the urban system: establishment of export oriented cash crop economy, development of colonial hierarchy of administrative centers on existing political centers wherever convenient and the creation of new administrative centers in less centralized traditional systems (Okonkwo, 1993).

At the creation of the Southern Nigeria in 1906, Lagos (figure 1.0) was chosen as the capital from among other towns because of its eminent position as a trading town with easy communication with Europe and easy communication with the interior part of the country through the railways which had been commenced from Lagos before the end of the nineteenth century. Another matter which weighed 
heavily in favour of Lagos was the existence of some rudimentary infrastructure like electricity supply. Even at that time, the possibility of removing the center of administration from Lagos to elsewhere was contemplated and it was thought that in a matter of 10 to 20 years the seat of administration might be moved from Lagos to another town. But it continued in Lagos, even after the amalgamation of the Northern and Southern Nigeria in 1914, in preference to Calabar and Port Harcourt which were also coastal trading towns.

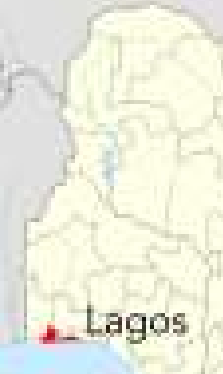

Figure 1.0: Map of Nigeria showing Lagos Source: Emekamozie.worldpress.com

Thereafter, it continued to be better developed than other towns and cities within the country. It was provided with pipe-borne water in 1915, and was declared a first class township in 1917 and had elected representatives on its council in 1920. In 1923, its existing electric power supply first installed in 1898 was extended. Five years later in 1928, a development board, the Lagos Executive Development Board, was set up with the general duty of planning the city and reclaiming some of the nearby swamps. The administration of the whole country continued there until the 1950's when the likelihood of independence for Nigeria came into sight.

The position of Lagos was one of the most controversial issues among political parties existing in the country before the coming into operation of the 1954 Constitution. In the end, it was the British Government that decided for Nigeria that Lagos should remain the Federal Capital and that the municipal area of Lagos should become Federal Territory and municipal area was excised from the existing Western Region and declared the Federal Territory under the administration of the Federal Government. This position became crystallized under the 1960 Independence Constitution which declared that Nigeria shall consist of three Regions and the Federal Territory was to comprise of the areas which, hitherto, had constituted the Lagos Town Council Area.

\section{Lagos in Conflict:}

Even though the 1963 Republican Constitution did not affect any change in the position, in so far as the Federal Territory was concerned, the actual problem of Lagos as capital of Nigeria began with the coming into effect on May 27, 1967 of the States (Creation and Transitional Provisions) Decree 1967, Decree No. 14 of 1967. That Decree divided the Federation of Nigeria into 12 states, one of which is Lagos State which includes the area previously referred to as the Colony and the then existing Federal Territory. Thus the administration of what had previously been Federal Territory came directly under a State Government, namely, the Lagos State Government. Another significant feature of Decree No. 14 of 1967 is that it added a subsection to section 2 of the 1963 Constitution by which addition Lagos was made the seat of the Federal Government. So, there was no constitutional or statutory provision declaring Lagos as the seat of the Lagos State Government (Okonkwo, 2006).

\section{Federal and State Government Conflicts in Lagos:}

From the foregoing, so long as the administrative functions of both the Federal and State Government are carried out within the same geographical territory of Lagos there was bound to continue to be conflicts. As would be seen, even in some cases where there is legal demarcation as between functions of the two Governments, this did not obviate the occurrence of conflict. As a result, the capability of Lagos to play such dual role diminished considerably. It may be argued that by proper administration this conflict could be totally eliminated but its achievement was reasonably remote as the Government was committed to a federal form of constitution for the country.

\section{The Desire for a New Capital of Nigeria:}

The desire for a new capital of Nigeria was founded on the increasingly diminishing capability of the Lagos territory to cope with the strong expansion of socioeconomic activity which accompanied the oil boom of the 1970s and the unavoidable increase in demand for greater efficiency in administrative management of the country. Within a very short period, within Lagos, land space, physical resources base, and urban infrastructure became inadequate at all levels. Added to these was the fact that the overwhelming majority of Lagos inhabitants were the 
Yoruba people, one of the major ethnic groups in Nigeria.

So, by a notice dated August 9, 1975, the then Federal Military Government of Nigeria set up a Committee with the following terms of reference:

A. To examine the dual role of Lagos as a Federal and State Capital, and advise on the desirability or otherwise of Lagos retaining that role;

B. In the event of the Committee finding that Lagos was unsuitable for such a role, to recommend which of the two Governments (Federal or State) should move to a new Capital;

C. In the event of the Committee finding that the Federal Capital should move out of Lagos, to recommend suitable alternative locations, having regard to the need for easy accessibility to and from every part of $t$ he Federation;

D. To examine all other relevant factors which will assist the Federal Military Government in arriving at the right decision.

After considering the Committee's report and findings, the need to transfer the capital of Nigeria from Lagos to Abuja (figure 1.1) emerged and as earlier indicated, in May 1967, Lagos became both the Federal Capital of Nigeria as well as the capital of Lagos State with the creation of states and the continued retention of Lagos as the Federal Capital was seriously questioned. The dual role became a source of embarrassing political and administrative complications with the result of that, Lagos became not only unlivable and unserviceable, but also ungovernmeble (Nwafor, 1980, Okonkwo, 2006).

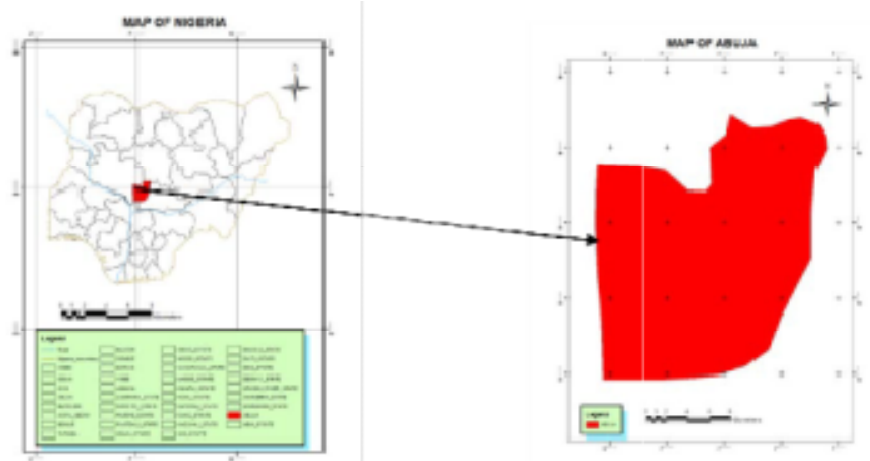

Figure1.1: Map of Nigeria Showing Abuja Federal Capital Territory

(Source: NARSDA Abuja) (October 22, 2016)

As a result of the peripheral location of Lagos, the city has tended to acquire a regional' rather than a truly national capital where provincialism is stronger than the feeling of the nation's unity. In Nigeria where there is an urgent need to create a national identity and preserve the country as a political unit, the 'created capital' should be so located as to convey a feeling of locational and functional neutrality' (Nwafor (1980), citing Stephenson, 1970, Okonkwo, 2006). In the process, the plan to relocate the capital of Nigeria from Lagos to Abuja (figure1.2) came in 1975 although; Abuja officially became the capital of Nigeria on 12, December 1991.

The concept of Abuja as a befitting Federal Capital Territory, centrally located and without the defects of Lagos was spawned in 1975 (figure 1.2). The site for the Federal Capital City was chosen for its location at the center of the nation, its moderate climate, small population and also for political reasons. To accomplish the goal of relocating the Federal Capital to an area, geographically central to Nigeria and with relative equal accessibility to all parts of the nation, about 845 villages were displaced to make way for the Federal Capital Territory (FCT) (Olaitan, 2004). The Government wanted an area, free of all encumbrances, a principle of "equal citizenship" within the territory where no one can "claim any special privilege of "indigeneity" (figure 1.1) as was the case with Lagos (Jibril, 2006, Okonkwo, 2006). It wanted all the existing population to be moved out of the territory. That was why it authorized not only a census of economic assets of all the inhabitants of the territory but also undertook to pay compensation for all their owners outside of the territory(Jibril, 2006, citing Mabogunje in Ayileka et al, 2001).

In the process of establishing a new nation's capital in Abuja, a Master Plan was developed. The Abuja Master Plan was elaborated to put in place, a sustainable urban spatial environment for all groups or classes of activities to be carried out in the Capital Territory. The development plan and process envisaged the seat of power would move from Lagos to Abuja in 1986, but this time of movement was brought forward to 1982/83; hence the commencement of urbanization stampeded. The most vulnerable, the urban poor had to arrange, on their own, where to live in order to stay close to work place and also reduce transportation and rent incidence on their income and that resulted in shanty settlements (in both formal and informal housing areas). 


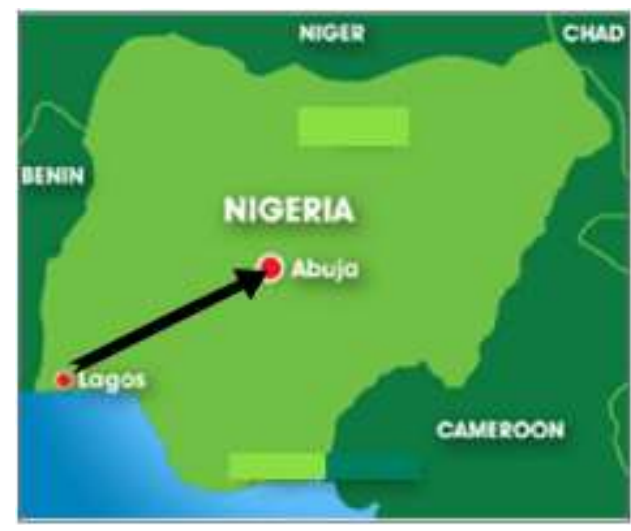

Figure 1.2. Nigerian map showing Lagos to Abuja Source: Google map (March, 2015)

The Master Plan was prepared such that land use, infrastructure, housing, transportation, recreation, economic and social services were to be coordinated and inter-related (Olaitan, 2004, citing Abba, 2003). Successive governments (Federal Government and the Federal Capital Territory (FCT) Ministry) in Abuja have neglected these principles (urban development standards). As such, series of distortions to the concept, direction and implementation of the Master Plan are prevalent (Olaitan, 2004).
According to Jibril (2006), "the first major policy statement made by Government in 1976, when it decided to move the Federal Capital of Nigeria from Lagos (in the coastal area) to Abuja (in the central part of the country) was for complete relocation of the entire inhabitants outside the new Federal Capital Territory, of about 8000 square kilometers. This was aimed at freeing the territory from any primordial claims, and to enable the Government to take direct control, plan and develop the new city without any encumbrance, but that was not the case within the governments of Abuja."

According to the Abuja Master Plan (1979), "the development of the city was designed to be in four phases with a clearly defined target population of three million inhabitants. The city was designed as an efficient and attractive environment at each stage of its growth - from Phase 1, which was designed to accommodate 230,000 residents through Phases II and III, which were to accommodate 585,000 and 640,000 respectively, to Phase IV aimed at accommodating 1. 7 million inhabitants (figure1.3)." Its ultimate population is estimated at 3.1 million (Olaitan, 2004).

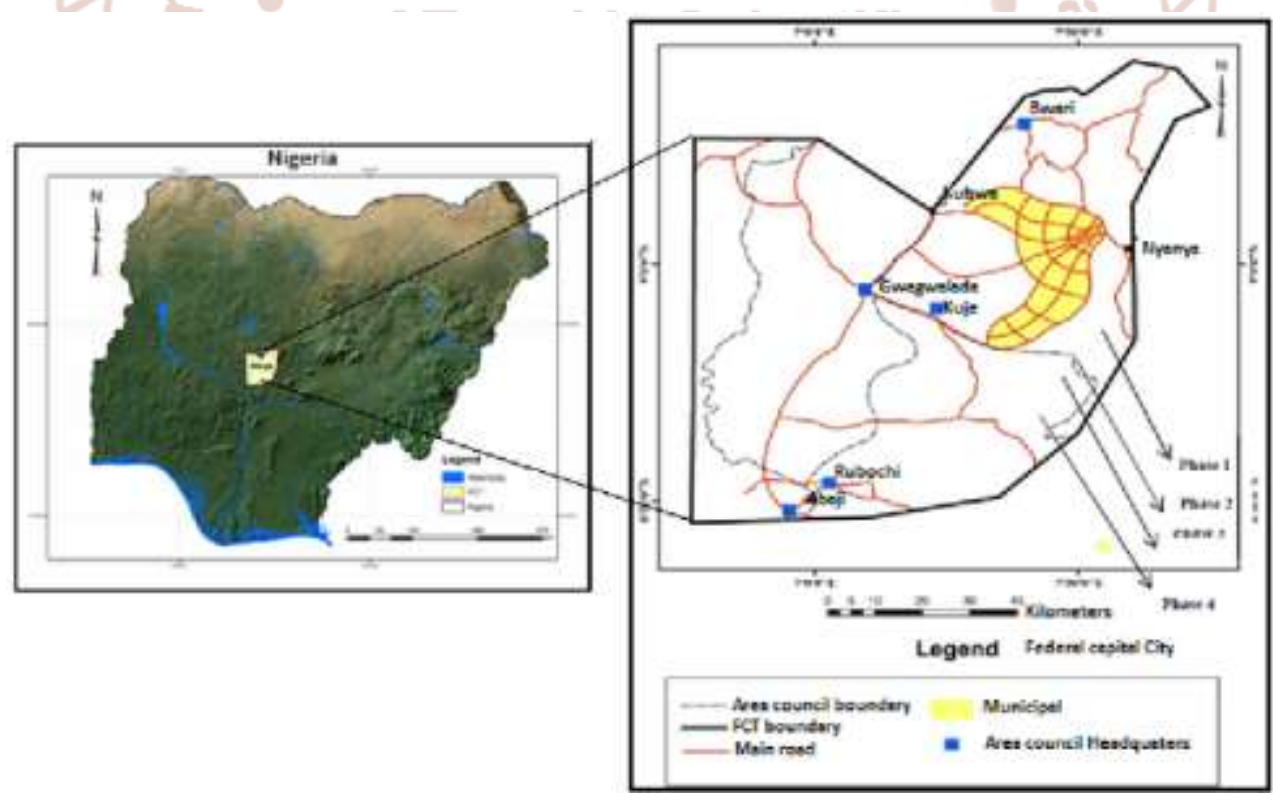

Figure 1.3: Abuja Map and the 4 Phase Development areas

Source: Research Gate (October 22, 2016)

The last known population of the Federal Capital Territory is 2, 440, 200 (population. city, 2016) while the 2016 estimates by T.I.N Magazine (2016), puts the Federal Capital Territory at 3, 100, 000 (Obiadi, 2017). As it is the case with development implementation in most developing nations, Abuja Master Plan was distorted, following different policy changes that affected the city. According to Jibril
(2006), "between 1976 and 2003, (a period of 27 years) there had been about four major policy changes affecting resettlement within the FCT." They are: (1), It was the original intent of the Abuja Master Plan to relocate the inhabitants, occupying the Federal Capital Territory area, however, careful enumeration later revealed that the figure was not 'few' - about 150,000 $-300,000$ people. Uprooting such a huge population 
was thought to be unwise and could have delayed the take-off of the project. It was then decided to allow the inhabitants to remain, but could be resettled within the territory, should their places of abode be affected by city development projects. (2), in some cases, at the time of relocation, plans were cancelled for political reasons. While the people affected were fully prepared for movement to the new location, another policy change happened (Jibril, 2004). (3), in preparation for the 2003 general election, the additional security personnel brought into the Federal Capital Territory occupied the buildings under the resettlement scheme (plate1.0). These major shifts in policy direction can be said to be the root cause of problems of squatters and Land Administration within the FCT (Jibril, 2006).

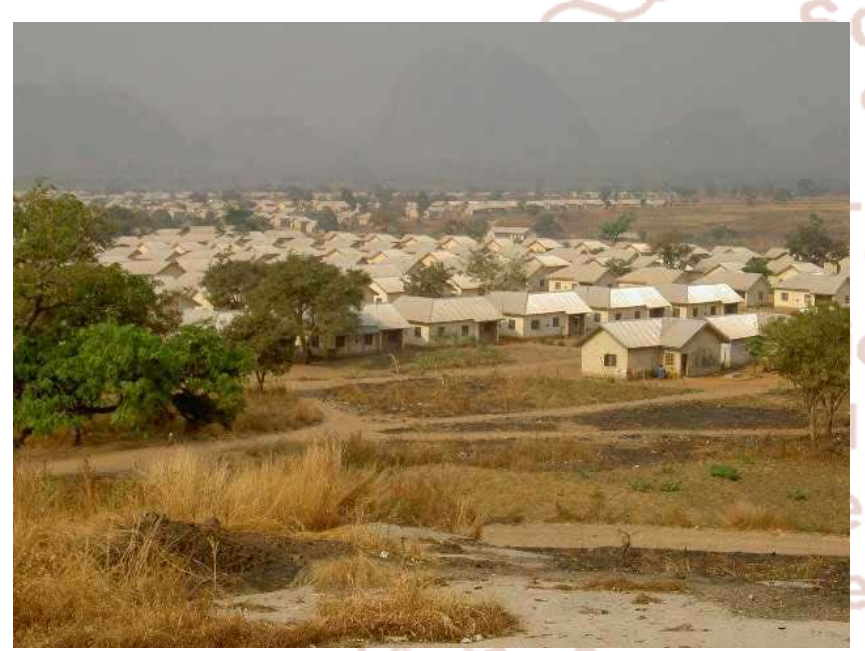

Plate 1.0. Resettlement village taken over by the Nigerian Police Force (fieldwork 2005) Source: Jibril (2006)

The derail and distortion of the Abuja Master Plan was also attributed to lack of professional personnel managing and planning the development of Abuja Master Plan. According to Jibril (2004), "the main cause of the distortions of the Master Plan was the creation of the Ministry of the Federal Capital Territory (MFCT) in 1980 and its being super imposed on the Federal Capital Development Authority (FCDA). The Ministry lacked the professional personnel to understand the philosophy of a Master Plan and the need for detailed planning and design to be carried out before the Master Plan could be transformed into construction activities in any part of the City."

Jibril (2004) further indicated that, "in 2003, a Ministerial Committee on Illegal Structures in the FCT was constituted to collate a list of all illegal structures in the FCT and present a strategy for demolition. Interestingly, most of the members of the committee were not professional planners."

The unplanned territorial growth and developments occurring in the Central Area of the City could also be traced back to the governments rush to relocate the government workers from Lagos to Abuja. These problems are as a result of the rushed movement of workers from Lagos to Abuja without adequate provision for accommodation. The result was the emergence of a number of shantytowns and squatter settlements occupied by workers and the growing service population in such places as Karu / Nyanya, Karmo and Gwagwalada because there were not enough housing accommodations in the Central City area of Abuja to house them and the majority of the houses in the Central City were too expensive for the low income workers. These settlements have grown rapidly and are generally unplanned, overcrowded and lacking basic amenities and infrastructure. Although, many of the rushed housing developments within the city area have had to be demolished, the shanty developments persist in the periphery of Abuja especially as there is still little provision for housing accommodation for the low-income workers within the city (Olaitan, 2004).

Adeponle (2013) observed "that Abuja city is growing faster (13\%) than the provisions of its Master Plan." It is fast turning into an environmental embarrassment, with developments springing up in gross isolation of zoning and other planning codes. Abuja, which was supposed to be an epitome of beauty and an enlightened vision of city development, has suffered over the years from unnecessary distortions in the implementation of its Master Plan. (Adeponle, 2013).

As a result of these changes in the Abuja Master Plan and policy inconsistences, the Abuja Central City designed to be a model city is not sustainable. It is divided between success and failures, rich and poor. It has potentials to flourish, but in most part, impoovished. The Central City is characterized by urban dialectics, dualistic living and infiltration of the formal settlement areas by informal settlers because of provision of services to the inhabitants of the formal settlement areas. There exist, a clear disparity in the socio-economic base of the two settlements yet, they co-exist. The two settlements co-existing within the formal settlement areas of the Central City are not integrated yet, because of nearness to their jobs and 
survival, the informal settlers infiltrating the formal settlement areas characterized as the urban poor, find their ways into the formal settlement areas of the Central City. In order to provide services and earn their living, the urban poor, through self-efforts, provide their shelters on government vacant lands, abandoned buildings and on city side-walks (plates 1.1, 1.2 and 1.3).The informal settlement areas within the Central City of Abuja are not integrated into the Central City infrastructure and that is one of the major challenges of the city as a result, promoting urban poor growth that resulted in squatter settlements (Obiadi, 2017).

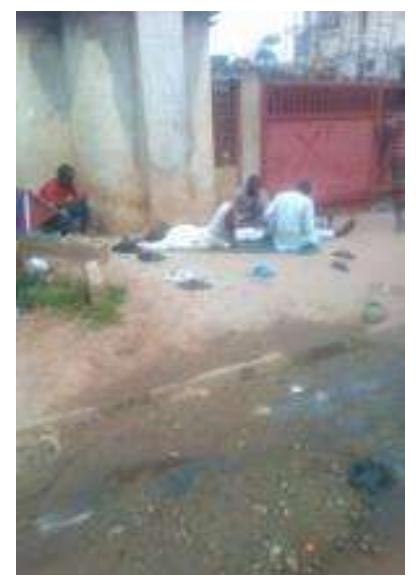

Plate 1.1. Abuja's public space (housing/shelter)

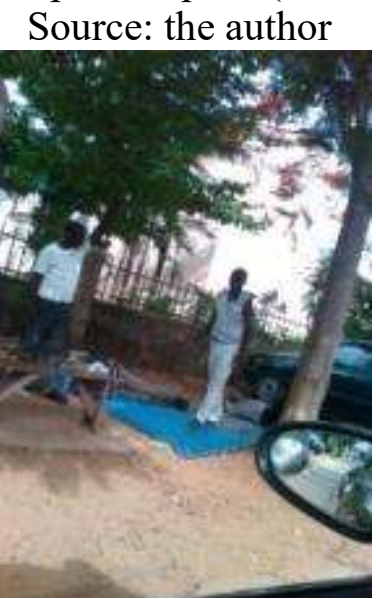

Plate 1.2. Abuja's public space (housing/shelter) Source: the author

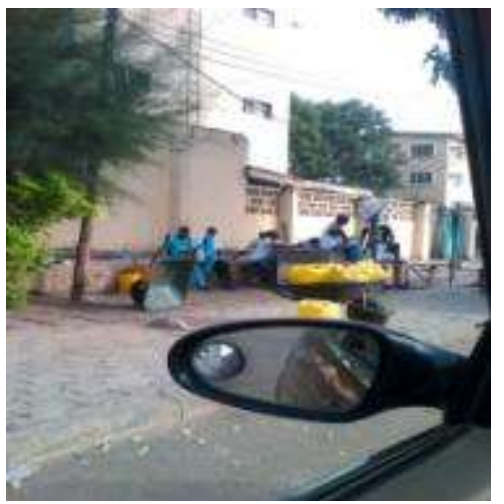

Plate 1.3. Abuja's public space (housing/shelter) Source: the author
A typical space becomes the shelter/house and the house becomes the space (for most of these people who are security guards, their relations and friends) in the case of urban poor and urban poor housing in Abuja. In most cases, these spaces are without spatially distributed objects yet, they are side by side with formal settlements without proper links and visually acceptable urban objects, elements and qualities. The nature of the socioeconomic complexity of these informal spaces, which analysis is shown in this paper, constitute a strongly identifiable character which is in this paper christened Spatial Housing. It is so termed because of the assumption of the public/open space into the provision of the basic (spatial) socioeconomic, psychological, shelter, etc. needs of the urban poor (Obiadi, 2018).

This phenomenon is different from those of the destitutes/homeless people in the city. The informal inhabitants are more or less fixed in location (even though improper location) and actively dependent on the socioeconomic activities of the urban economy. To that effect, Abuja urbanization is growing more than the area's urban development vis-à-vis housing and economic resources. In the formal sense, spaces can be defined and differentiated, however same cannot be said in the informal, hence 'spatial dialectics'. Within the space is the spatial housing characterized by informal volumetric and unvolumetric combination now called the 'spatial house', 'open house' or 'house without limit (plate 1.1, 1.2 and 1.3).

\section{All the Abuja government's housing programmes} have failed.

$>$ The housing provided by the Abuja government failed because of inadequacy of housing and a good access to the central facilities through a corridor of open spaces and lack of economic connectivity (secondary employment).

> The Master Plan was prepared such that land use, infrastructure, housing, transportation, recreation, economic and social services were to be coordinated and inter-related (Olaitan, 2004, citing Abba, 2003), but that was not the case during the implementations.

Much of our daily experience of the city occurs within the collectively shared public spaces, or the public domain. Not only does the public domain provide for most basic of the city's functions, access, but it also provides for and contains many other functions and activities synonymous with 
urban life. These are lacking and the problem with Abuja's environmental and urban development.

$>$ Prior to 1973, government activities in public housing had been quite sectional and favored only the working class elites in the society. The poor and low-income were relegated to the background (Olu-Sule, 1988).

$>$ The Abuja government's housing programmes have not worked. The provided Federal Housing units were developed without adequate economic and municipal service facilities as a result, the housing units are not sustainable and also, inadequate for the Abuja steaming population. It equally fail because of the government rush to move government workers from Lagos to Abuja when the government has not provided adequate housing for the workers

$>$ Not only that, the Capital City was planned to be built by the Federal Government in its greater part. The Master Plan actually provided for lowincome settlements (housing) areas, to be built by the government and to be occupied by the public servants; the private sector servants did not appear to be properly provided for.

The government's approaches to solving the problems of the urban poor housing issues in Abuja Federal Capital Territory have not yielded a reliable solution; especially in the area of urban spatial distribution being created by the invasion of the formal by the informal urban dwellers; and to start solving them, this paper explored sustainable spatial integration and retention of the urban poor settlement areas that architecturally bridged the gap (spatial solution) between the urban poor settlements (place of abode) and place of work; thus, evolving a sustainable spatial housing design for the urban poor in Abuja (Obiadi, 2017).

\section{STATEMENT OF THE PROBLEM}

As seen from the background, the stampeded relocation of the Nigerian capital city from Lagos to Abuja already created the dislocation of Abuja Master Plan implementation. Subsequent to this, is the lack of adequate urban infrastructure, facilities and amenities for the relocated population. These, accompanied by rapid urbanization resulted in spontaneous growth of slums, shanty towns and ghetto settlements in the city centre and surrounding territory. These informal settlements are partly of the original indigenes and partly settlers, who were cut up by urbanization process. The situation is heightened by demolition exercises especially, during the Mallam Nasir el-Rufai administration of the Federal Capital Territory, from 16 July 2003 to 29 May 2007and steady influx of migrants which cumulatively have resulted in greater population having no housing and sustainable residential environment, and the formal areas being invaded by the informal urban dwellers.

\section{AIM OF STUDY}

The present work aims to evolve modalities for spatial housing design capable of remedying the existing urban spatial distortions, in a sustainable manner within the Central City areas.

\section{METHODOLOGY}

The authors adopted content base analysis, targeted data from both primary and secondry sources including, photographs, previous works that looked into architectural solutions of urban population problems in relation to housing provisions, spatial integration, socioeconomic and physical character of the urban poor settlements areas, their conditions, community views, perceptions and their process of change or urban dynamics.

\section{DRIFT IN ARCHITECTURE AND URBAN PLANNING}

A global perspective tells the story of this global shift and transformation, highlighting the role of architects, urban designers, planners and their clients: central government, local governments, communities, nongovernmental organizations (NGOs), developers and world institutions in city planning and development (Shane, 2011: 12). This is accomplished through the urban actors and the urban actors adopt urban design models and elements to achieve that goal in city planning, development and transformation. The first theme (model), in city transformation is that, the urban actors need to cooperate not only in building the city, but to maintain and regenerate it, to modify and transform it. Cities are about people living together, and this requires organization and skills in managing the affairs of the local community and larger city (Shane, 2011: 14).

According to Shane (2011), as cities have grown, so has the need for organization that leads to the second theme of cybernetics: urban modeling and selforganization. This enables the urban actors to process far more information than before, looking for selforganizing, interactive patterns and emergent conceptual models in the complexity of cities in the 
1960s. The third thread in this story of urban transformations is the idea that urban actors manipulated a limited set of urban elements in building their urban models and cities. The three important urban elements employed by urban actors in constructing cities are enclaves, the armature and the heterotopia.

Enclave is a more or less bounded space like a field in the countryside, a piece of urban property with a wall around it or an open space like a square at the centre of a city surrounded by buildings (Shane, 2011). Enclave, a part of a country entirely surrounded by foreign territory: viewed from the position of the surrounding territories (Collins, 2012).

An armature is a linear spatial organizing device, like a street or highway with sequential, numbered houses or axits. Urban actors often use armature as the approach to an enclave, to cut through enclaves or as the link between two attractors (Shane, 2011). The concept of "urban armatures," referring to any set of main streets, plazas, and major public buildings linked by means of arches and fountains that connect one end of the city with the other, has been chiefly analyzed in central and western Roman contexts (MacDonald 1986). Before MacDonald's study, the prevailing viewpoint held that Roman city planners in the Republican period and into the Augustan age imitate Greek models based on rigidly orthogonal axes (e.g., Ward-Perkins 1974).

In contrast, MacDonald stresses the innovativeness of Roman cities in their organically-generated urban armatures. The prolonged development and additive nature of these urban armatures contrast starkly with customary notions of theoretical city planning. Instead of following a strict gridded plan, this theory demonstrates how a flowing spatial unity pulls strolling pedestrians along from city gates to allimportant forum complexes in the city center, easing the transition from one region to the next. The traditional way of studying and visualizing a city's urban development uses multiple diagrams denoting public buildings, communal spaces, and residential areas present in a given period (Ratté 2008). Figures 1.4.and 1.5, looked at two different models of urban armatures and how city actors manipulate the spaces for the comfort of the users.

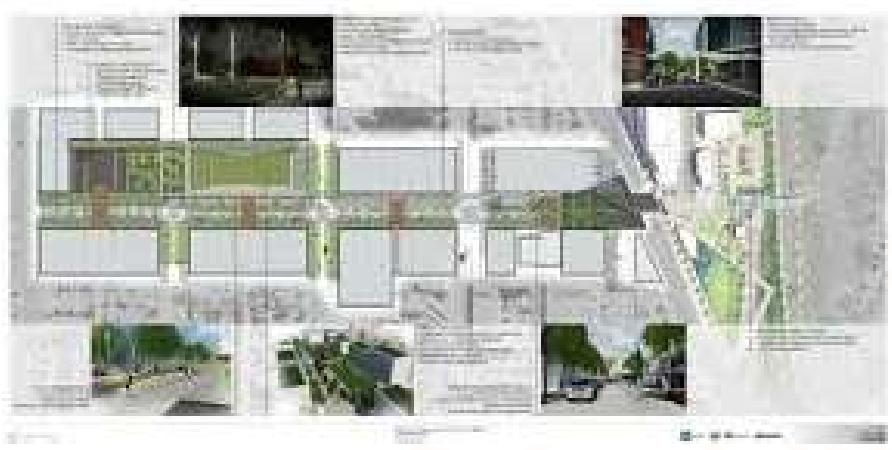

Figure 1.4.Edmonton, Canada Redevelopment plan's Armature Source: Google (September 26, 2015)

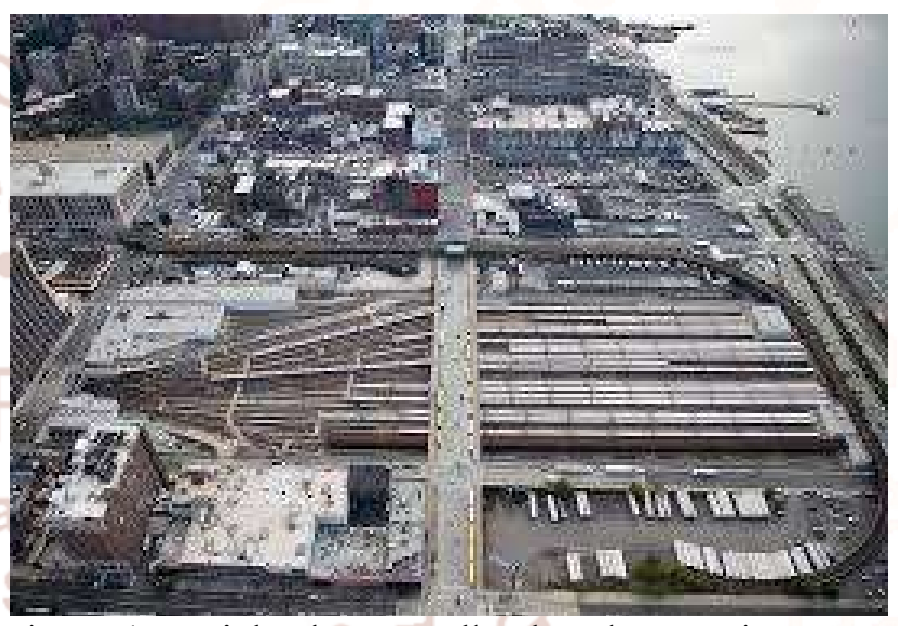

Figure 1.5.Michael Van Valkenburgh Associate Inc's Project Image (vvainc.com)

Source: Google (September 26, 2015)

Heterotopia is a specialized urban element, an enclave that has multiple interior subdivisions that can hold conflicting urban activities in the same place at the same time (often in section). It is an important place for urban experimentation and change, handling nonconforming urban activities and contributing to the overall ability of the city through its capacity to host change (Shane, 2011).

Shane (2011) further indicated that heterotopia was borrowed from French philosopher, Michael Foucault's writing that pointed at prisons, hospitals, clinics, asylums and courthouses as heterotopias of deviance that help to give birth to modern city by removing people who were ill, could not work or did not fit in the city, accelerating the shift to modern, efficient industrial society.

Throwing more light, Foucault (1979) indicated that, heterotopia is a concept in human geography to describe places and spaces that function in nonhegemonic conditions. These are spaces of otherness, 
which are neither here nor there, that are simultaneously physical and mental. Over the years, a dazzling variety of spaces have been explored as illustrations of heterotopia, including: Arab-Islamic architecture, environmental installations, libraries, museums, Masonic lodges, early factories, gardens, performance prototypes, women's colleges, landscapes, gated communities, Buddhist sites, band rooms, pornographic sites, cybercafés, shopping malls, burial sites and the body of the vampire (Foucault, 1979).

The fourth thread the urban actors used in city transformation involves the ability of urban actors to reflect on their work, reorganize elements and transform models to fit local circumstances and time. This ability to reflect, adapt, discuss and change is very important to the continual creation of new urban forms and the adaptive reuse of older ones (Foucault, 1979).

\section{ANALYSIS AND FINDINGS}

In the field, the authors, found formal (well surveyed settlements) and informal housing [urban poor settlements (slums)] in Abuja, characterized by Quick-Fix (make-shift) homes, mostly built / with recycled wood, zinc and aluminium products and from construction sites (panels 1.4 to 1.19). The settlements have homes in total disrepair; the areas littered with waste and unkempt (even at the middle of formal housing areas). The majority of the settlements have narrow and overflowing dirty gutters that zigzagged around the make-shift homes (plates 1.6 to 1.193 ). They lacked infrastructure, but could be linked up with the surrounding Central City infrastructure.

\section{STATEMENT OF FACTS}

$>$ The Abuja Master Plan was elaborated to put in place, a sustainable urban spatial environment for all groups or classes of activities to be carried out in the Capital Territory.

$>$ The Capital City was planned to be built by the Federal Government in its greater part. The Master Plan actually provided for low-income settlements (housing) areas, to be built by the government and to be occupied by the public servants; the private sector servants did not appear to be properly provided for.

$>$ The development plan and process envisaged the seat of power would move from Lagos to Abuja in 1986, but this time of movement was brought forward to $1982 / 83$; hence the commencement of urbanization stampeded. The most vulnerable, the urban poor had to arrange, on their own, where to live in order to stay close to work place and also reduce rent incidence on their income and that resulted in shanty settlements (in both formal and informal housing areas).

Within the high, middle and low density residential areas are pockets of slums, ghettos and outside shelters." Outside shelters are mostly occupied by security men and their family members, servicing the high, middle and low density areas(see plates 1.1 to 1.3). The Abuja government failed to clearly define and determine who the urban poor in Abuja are and concentrated efforts in finding solutions on how to solve the resettlement problems of the original inhabitants of the Abuja land, that according to the Abuja Master Plan, were to be relocated and clear the Abuja territory of all encumbrances. The Capital City was planned to be built by the Federal Government in its greater part. The Master Plan actually provided for low-income settlements (housing) areas, to be built by the government and to be occupied by the public servants; the private sector servants did not appear to be properly provided for.

\section{Determining the demographic and socio-economic} characteristics of the invading informal, squatters.

Eeconomically, the Abuja urban poor communities (even in the formal settlement areas) are characterized by mini commercial services, mainly minimal provision shops, provision kiosks, kerosine stands, fire wood stands, shoe repair stands, beer parlors, restaurants, charcoal stands, vulcanizers, yam frying stands and a list of other similar mini economic activities as documented on some of the pictures in plates 1.4 to 1.15 .

\section{Some Abuja slums / Public Housing Types (Abuja urban poor housing typology)}

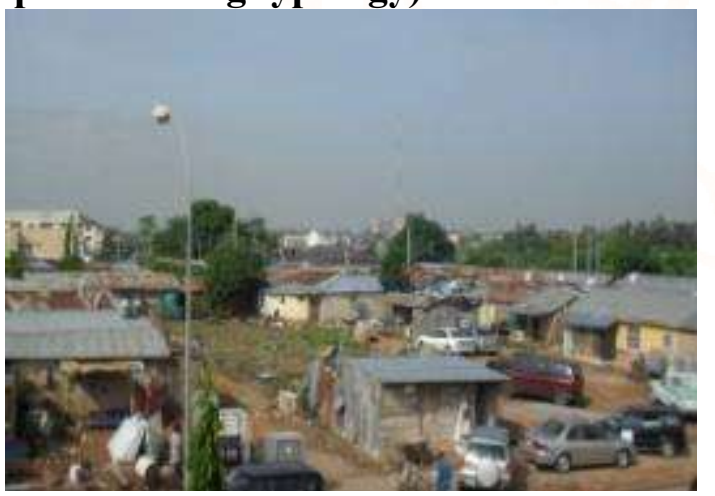

Plate 1.4. Utako Settlement area

Source: the author 


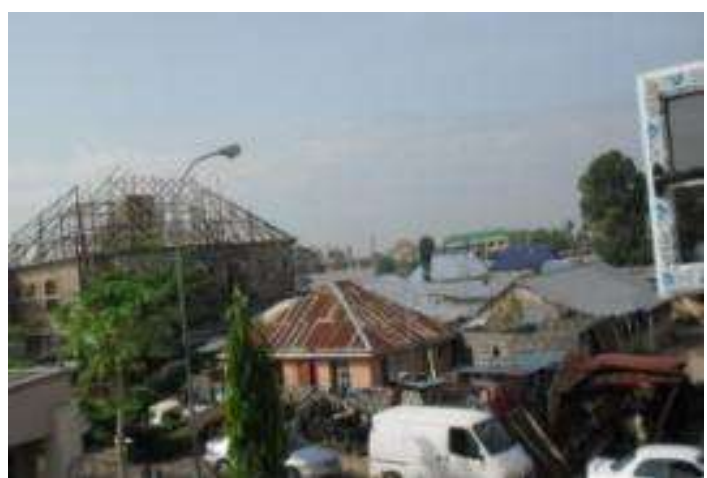

Plate 1.5. Utako Settlement area Source: the author

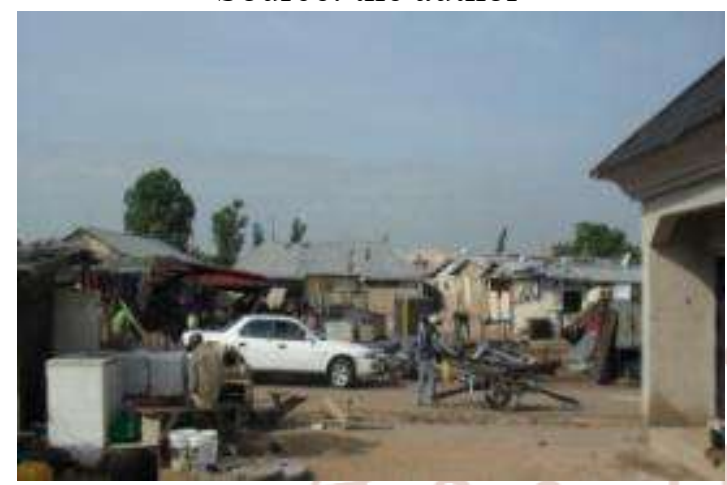

Plate 1.6. Utako Settlement area Source: the author

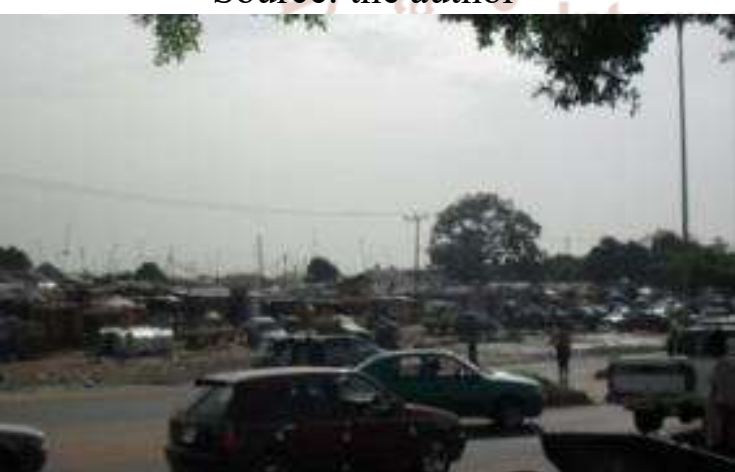

Plate 1.7. Utako Settlement area

Source: the author

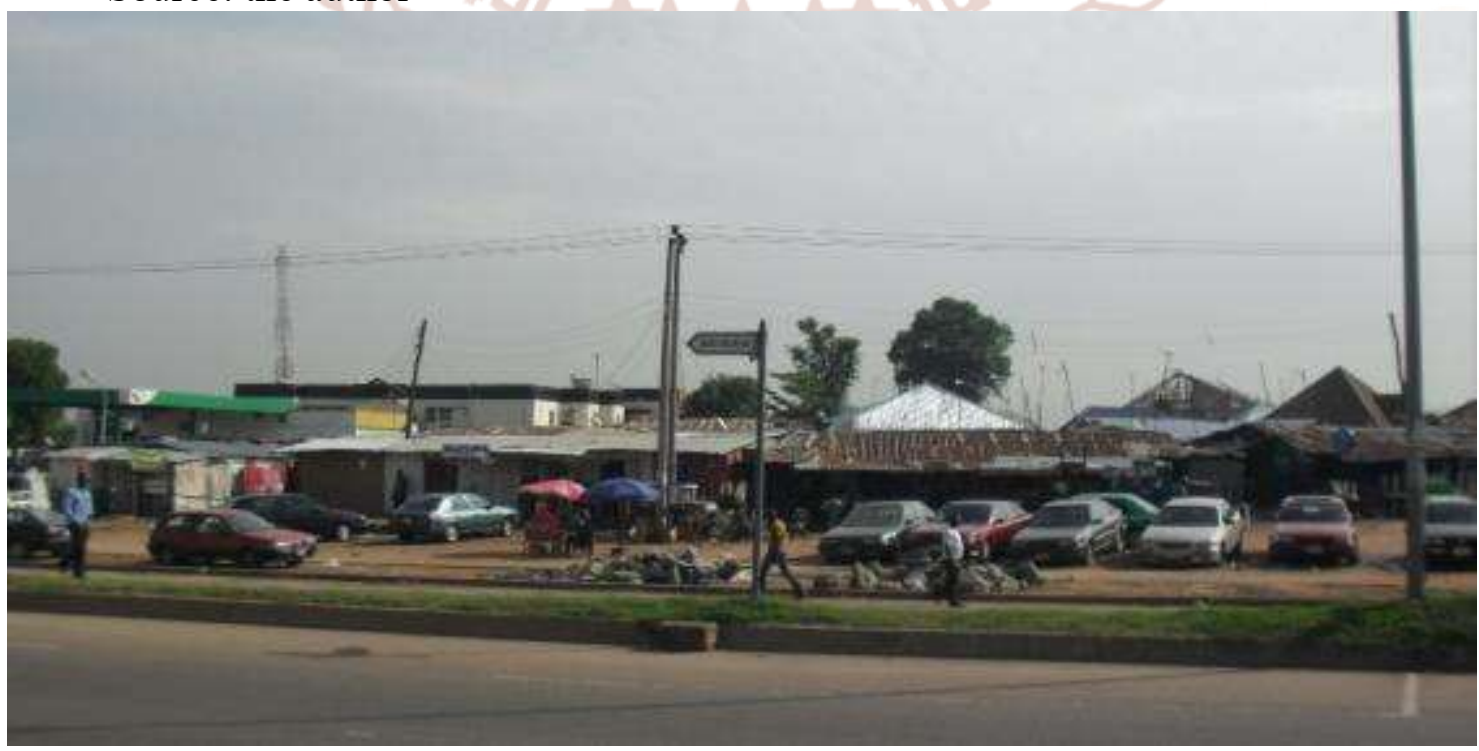

Plate 1.10. Jabi Village, Obafemi Awolowo Way

Source: the author

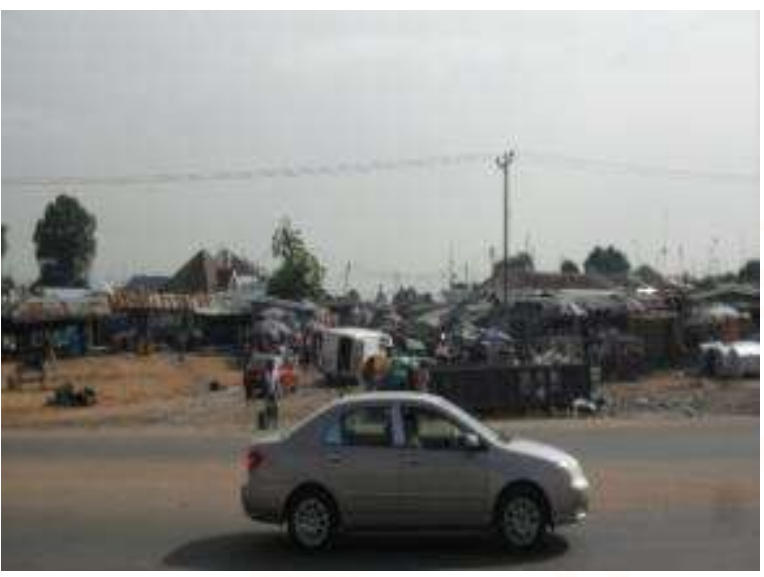

Plate 1.8. Utako Settlement area Source: the author

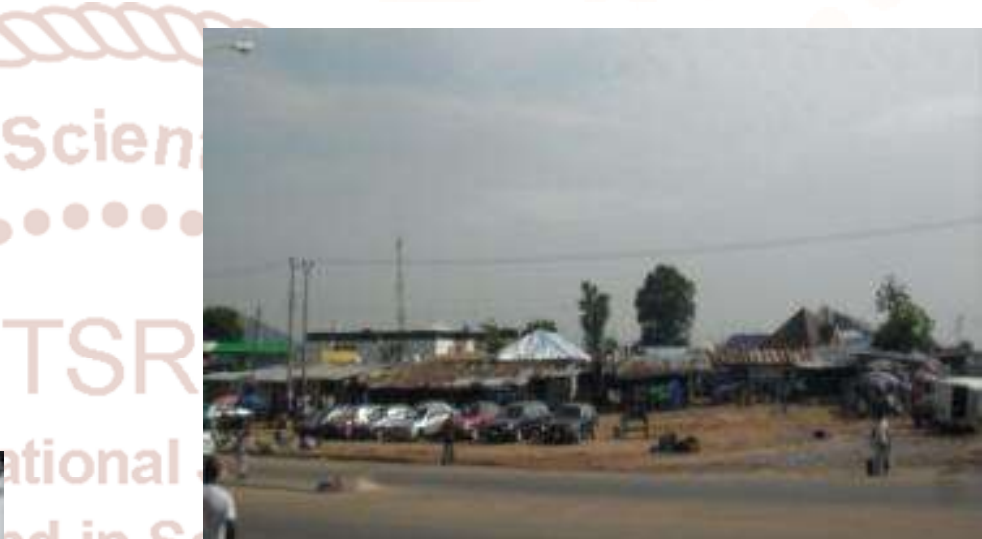

Plate 1.9. Utako Settlement area Source: the author

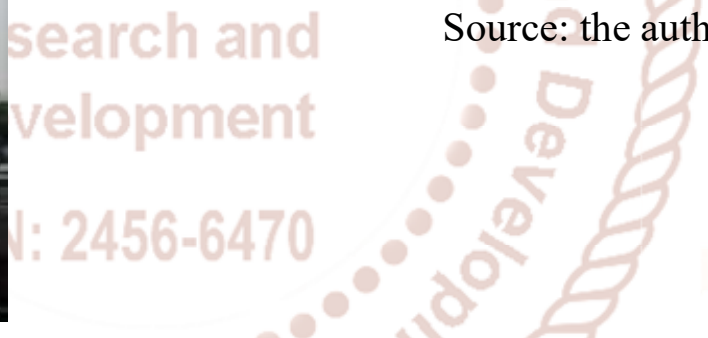

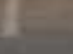




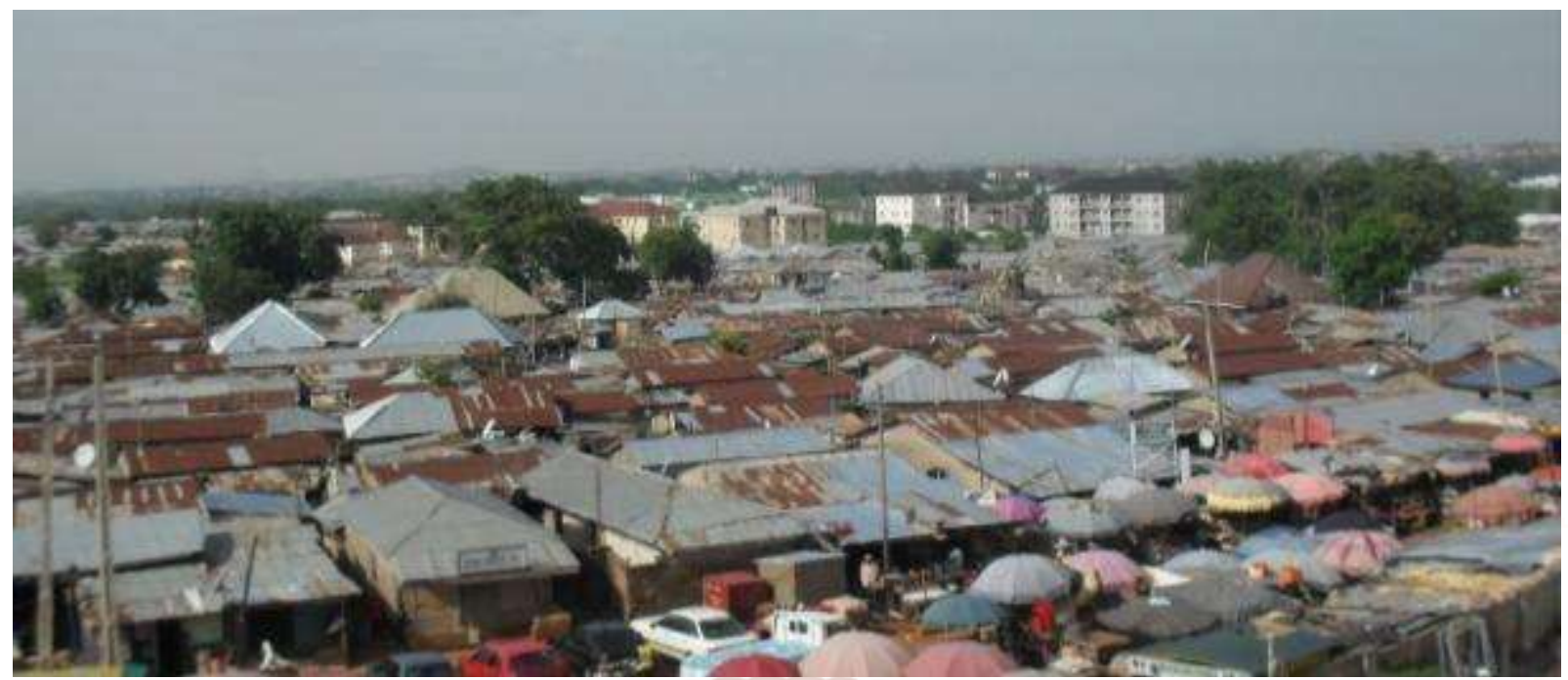

Plate 1.11. Jabi Village, Obafemi Awolowo Way Source: the author

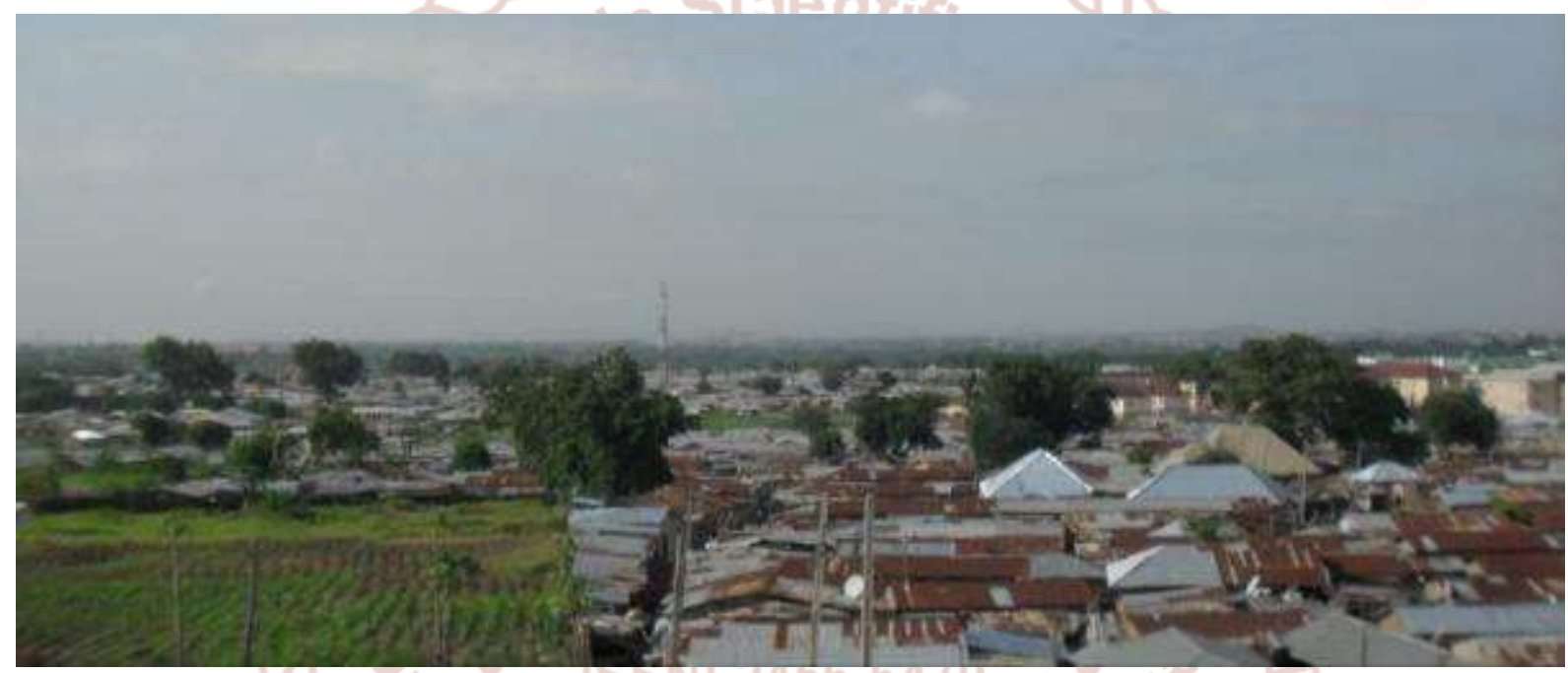

Ylate 1.12. Jabi Village, Obafemi Awolowo Way

Source: the author

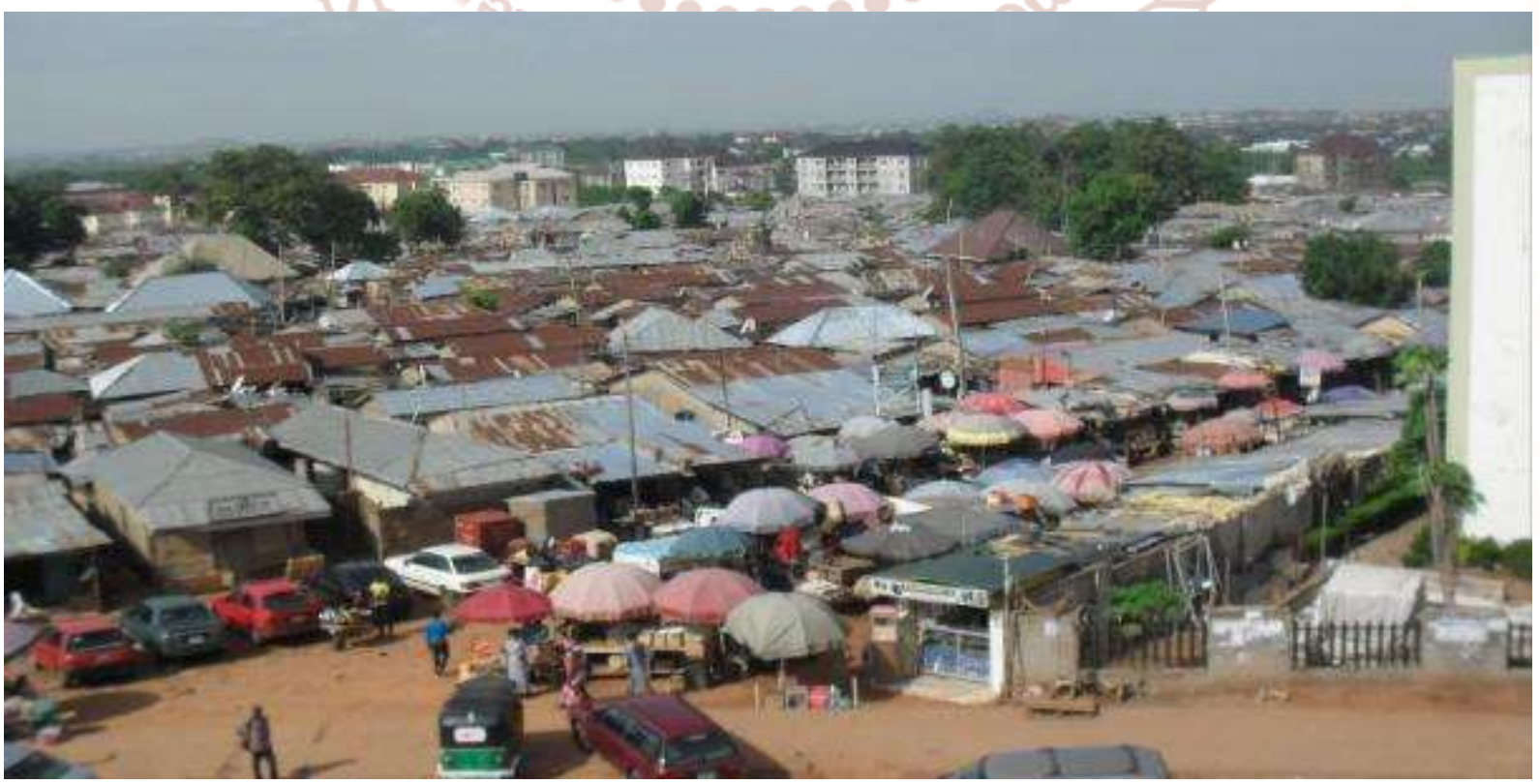

Plate1.13. Jabi Vllage - I. T. Igbani Street

Source: the author 


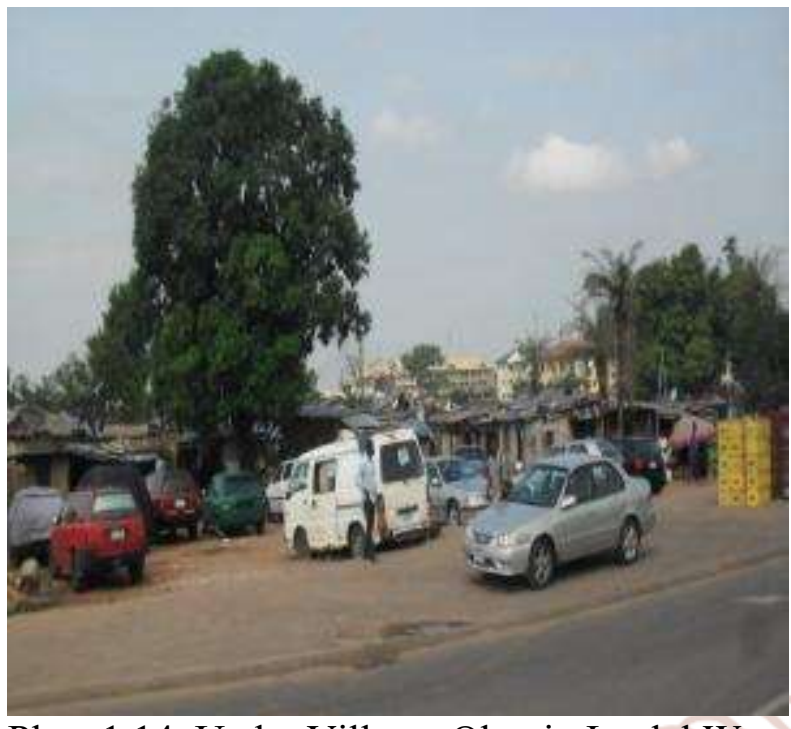

Plate 1.14. Utako Village, Okonjo Iwulal Way Source: the author

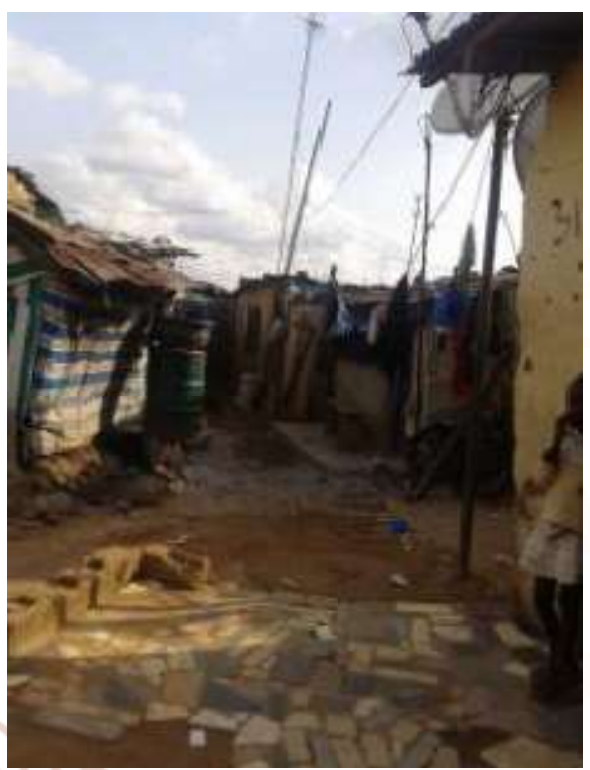

Plate 1.17. Utako settlement area

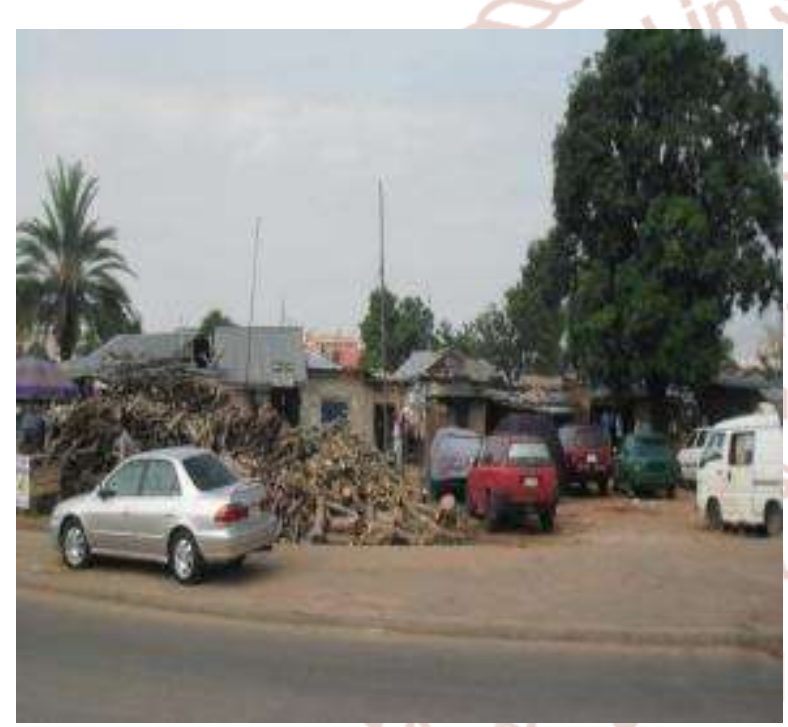

Plate 1.15. Utako Village, Okonjo Iwulal Way

Source: the author

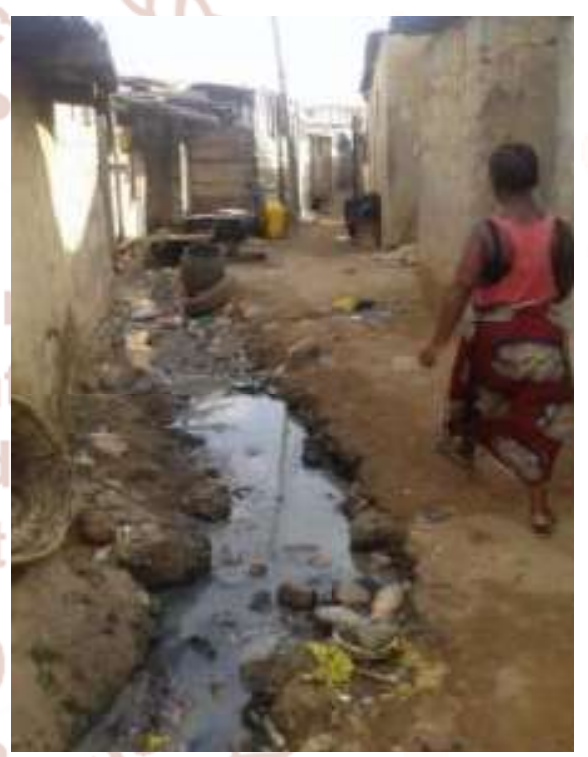

Plate 1.18. Utako settlement area

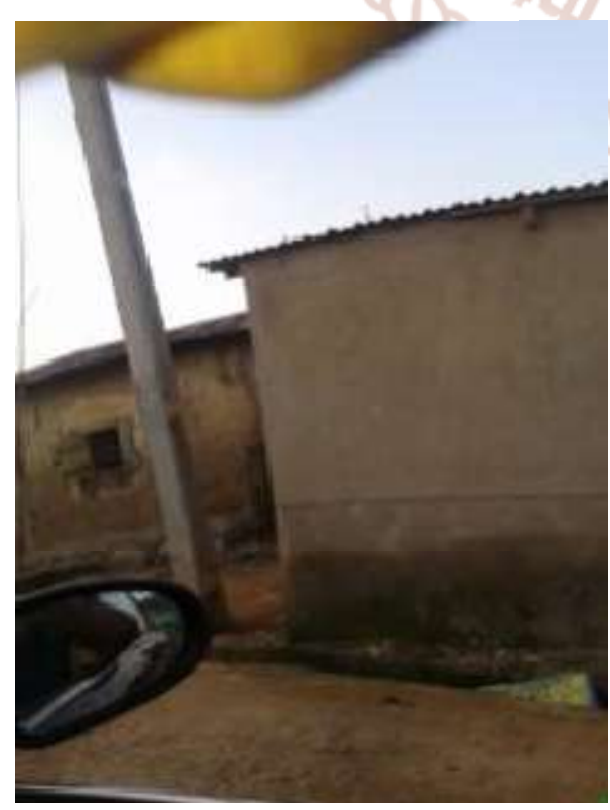

Plate 1.16. Utako settlement area

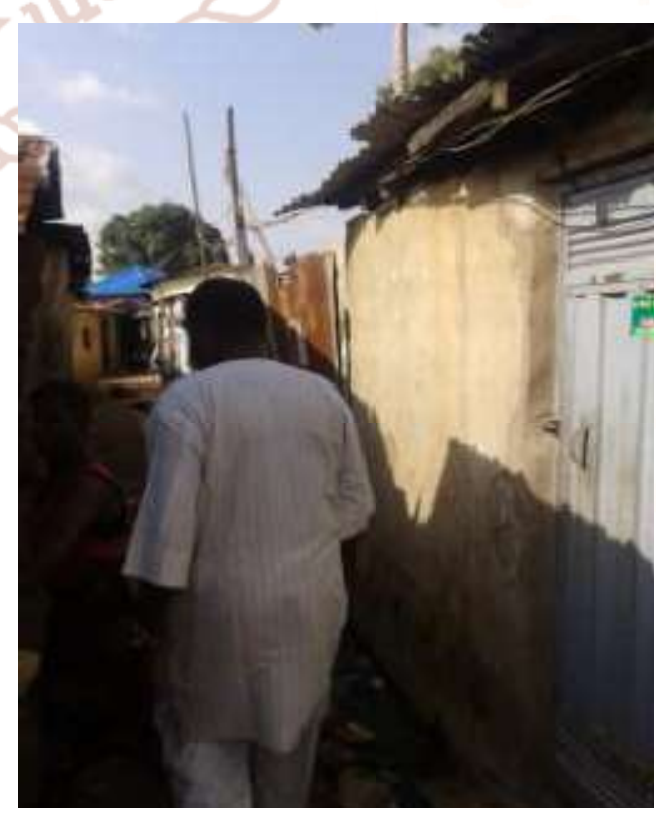

Plate 1.19. Utako settlement area 
Does the Abuja Master Plan provide for urban development facilities for suitable level of urban activities (adequacy of the Master Plan in general)?The Abuja Master Plan was elaborated to put in place, a sustainable urban spatial environment for all groups or classes of activities to be carried out in the Capital Territory. Yes it provided however, the implementation was not adequately carried out and that resulted in what this paper called "spatial dialectics" especially in spatial distribution of objects. It resulted in the city been characterized by dual urban spaces: the formal (where all is organized) and informal (undeveloped squatter settlement). These all started when the development was planned in such a way that no settlements or people affected would become separated from their "kith and kin" or be rendered "homeless" in the sense that a whole ethnic group may regard themselves "homeless" if their entire land were taken away from them and they were asked to go to settle in lands belonging to other ethnic groups. This however, is not the case. A lot of the displaced people of Abuja land found themselves in areas without their "kith and kin" and in most part, rendered "homeless" and in slums.

The level of development attention in these layouts presupposed complete relocation of the villagers to larger villages outside the Capital City; these larger villages formed the basis of the Regional Plan recommendation for development of series of satellite towns to support the Capital City, but was not the case.

The Abuja Master Plan called for the new capital residential communities to be organized around households sharing daily public services which are within walking distances. Such communities vary in size depending on sharing patterns orientation to transportation facilities, residential density, natural physical boundaries, etc. An examination of urban patterns in existing Nigerian cities supports the importance of permitting such factors to reinforce traditional ties of social, cultural, occupational and administrative groupings in evolving a sense of community which can contribute to residential satisfaction. However, the application of this concept in building the new capital implied a physical expunge of the local communities and complete loss of their identity within the city; the names of the villages are retained but the villagers and their settlements are no longer there. Within residential communities, housing dominants land use as well as the most direct point of contact between the new city and its residents. The housing program for the city was formulated to strike a balance between the improved standards of housing which the public and private sectors wished to provide and the costs the city's residents could afford; but seemingly without strategy to involve those who originally inhabited the area because they have been asked to relocate outside the capital city.

\section{RECOMMENDATIONS}

It is the recommendation of this paper, for the Abuja government to review and change her typical ways of implementing government policies. The governments in Nigeria have in the past, developed housing programmes for the urban poor without urban architecture or urban design attributes, contributions of the inhabitants and consideration of their interests and those are, part of the problems with the Nigerian housing delivery programmes and needed to be changed.

Strict adherence to the goals and objectives of the Master Plan, development laws, the use of professionally trained staff in the execution and implementation of the Master Plan and integration of the informal settlements into the formal settlement areas of the Central City. To promote growth and integration, allocation of Certificate of Occupancy (C of $\mathrm{O}$ ) to the residents at the present locations of the settlements is strongly recommended.

Granting and giving lands to the residents of the urban poor settlements of Abuja, to enable them build and economically develop their settlements with the use of high rise ( 4 to 6 story apartments) and row housing would bridge the existing gap between the formal and informal settlements of the Central City.The government could build the buildings and rent them to the urban poor on a subsidized rent to own basis. The retention and sustainable spatial integration of the urban poor settlement areas, with urban planning elements and architecturewould bridge the gap (spatial solution) between the urban poor settlements (place of abode) and place of work.

\section{CONCLUSION}

The current Abuja settlement patterns (formal and informal) are not speaking in terms of integration. There is, inexistence, adverse economic inequality and injustice within the Capital City of Abuja and the need for the formal, informal settlements and the 
Abuja urban actors to be talking, to link the informal and formal settlements together and tie them into the Central City infrastructure. The poor implementation of the Abuja Master Plan, led to dismal miscommunication problems and economic divide within the Abuja Capital City. The city lacked integrity, inclusion of all and shared prosperity. It is a model capital city that lacked inclusive economic growth incentives and from the study findings, not sustainable.

The current situation favors the rich and only through balanced economy can a better society be made of the Abuja Capital City. Share values make for a stronger society. The Abuja urban poor are calling for freedom and dignity by economic integration of the formal and informal settlements. It is understandable that, when your neighbor is successful you want to be successful too. The Abuja Capital City needs to be interconnected with the unstructured segments of the city. The formal and informal settlements of the Abuja Capital City should be talking to each other instead of talking at each other. Abuja's diversity needs to be turned into treasure for the inhabitants, both in the formal and informal settlements.

\section{REFERENCES}

1. Abba. A (2003) Saving the City of the Abuja from Dir, Faeces, Garbage and Disease. In-depth Analysis Vol 3, N0 5 Nov 2003

2. Abuja Master Plan (1979). The Master Plan for Abuja. The New Federal Capital of Nigeria. Federal Capital Development Authority (FCDA), State House, Marina, Lagos, Nigeria.

3. Adeponle B. J (2013). The Integrated City as a Tool for Sustainable Development. Journal of Educational and Social Research Vol. 3 (5) August 2013

4. Ayileka, O. \& Kalgo, M. S. U(eds.) (2001), The Review of Abuja Master Plan:- Proceedings of an International Workshop for the Review of the Abuja Master Plan, held in Abuja, 9 November 2 December 1999. Ministry of the Federal Capital Territory, Abuja.

5. Bell, M. (1981): "Modern Sector Employment and Urban Social Change: A Case Study from Gaborne, Botswana," Canadian Journal of African Studies, 15, 259-76.
6. Collins William (2012). Collins English Dictionary - Complete \& Unabridged 2012 Digital Edition (C) William Collins Sons \& Co. Ltd.

7. Foucault, Michel (1971 and 1979). The Order of Things. New York: Vintage Books.

8. Jacobs, J. (1969): The Economy of Cities, Penguin, London.

9. Jibril Ibrahim Usman (2006). Resettlement Issues, Squatter Settlements and Problems of Land Administration in Abuja, Nigerian's Federal Capital. Promoting Land Administration and Good Governance, $5^{\text {th }}$ FIG Regional Conference, Accra, Ghana. 1-13.

10. Mabogunje, Akin (1968): Urbanization in Nigeria, University of London Press, London, pp.107-108.

11. MacDonald, W. 1986. The Architecture of the Roman Empire: An Urban Appraisal. Vol. 2. New Haven: Yale University Press.

12. Mumford, L. (1961): The City in History, University of London Press, London.

13. Nwafor, J. C., (1980). Department of Geography, University of Nigeria, Nsukka, Nigeria. GeoJournal 4.4 359-336/1980 Akademische Vetlagsgesellschaft, Wiesbaden

14. Obiadi, B. N. (2017). Evolving Modalities for Sustainable Spatial Housing Design for the Urban Poor in the Federal Capital Territory, Abuja, Nigeria. Department of Architecture, Faculty of Environmental Sciences, Nnamdi Azikiwe University, Awka, Anambra State, Nigeria

15. Okonkwo Moses M (2006). The Building of a New Capital and its Local Communities: Abuja Federal Capital City in Focus. Public Space as an Element in the Shaping of Local Societes. Urbanistyka Miedzyuczelniane Zeszyty Naukowe NR 11/2006. P68-85.

16. Okonkwo, M. M. (1993): "New Pattern of Development for Cities in Nigeria" Unpublished Ph.D. Dissertation Warsaw, University of Technology, Warsaw, Poland.

17. Olaitan, Danmole Taibat (2004). Sustainability and City Development. A Critique of the Implementation of the Abuja Master Plan. Department of Urban and Regional Planning, University of Lagos, Akoka-Yaba, Nigeria.

18. Olu-Sule, R. A. 1988. Housing and Environmental Planning: A Synopsis on Urban Development in 
Nigeria. Wusen Press Ltd. 18 Ekpo Abasi Street, Calabar. P114-115

19. Pitte, J. R. (1977): Nouakchott: Capitale de la Mauritanie, Dept. de Geographie de L'Universite de Paris - Sorbonne, Paris.

20. Shane, David Grahame. 2011. Urban Design Since 1945: A Global Perspective. Everbest, China

21. Stephenson, G. V. (1970). Two Newly-Created Capitals: Islamabad and Brasilia. Town Planning Review 41, 317-332

22. Ukwu, I. U. (1980): "Urbanization and its Implications for the Development of Nigeria", in Readings in Social Sciences, Fourth Dimension Publishers, Enugu. Pp. 167-182.

23. Uloko, C.O. (2005) "The Abuja Master Plan: The Need for a Better and Sustainable Outlook in International Circles", in Built Environment Audit, Nigerian Institute of Architects, Lagos.

24. Walter Christaller (1966). Central Places in Southern Germany. Translated by journals.sagepub.com/doi/abs/10.1177/000271626 636800132. Pp. 230

25. Word Perkins, J. (1974). Cities of Ancient Greece and Italy: Planning in Classical Antiquity. New York. George Braziller 